\title{
6356 SAYILI KANUN KAPSAMINDAKİ KURULUŞLARDA DİSIPLIN UYGULAMALARI
}

\author{
Discipline Practices in Organizations within the Scope of Code No 6356
}

\author{
Ümit ORHAN*
}

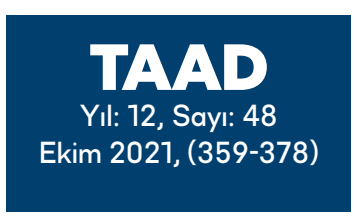

\section{$\underline{\text { Makale Bilgisi }}$}

Geliş Tarihi : 06.04.2021

Kabul Tarihi : 14.09.2021

Makale Türü: Araştırma

\section{Article Info}

Received Date: 06.04.2021

Accepted Date: 14.09.2021

Article Type : Research

\section{ÖZET}

Disiplin, bir topluluğun, yasalarına ve düzenle ilgili yazılı veya yazısız kurallarına titizlik ve özenle uyması durumudur. Disiplin, herhangi bir organizasyonda olduğu gibi sendikal kuruluşların da amaçlarına ulaşabilmesi için gereklidir. Kuruluş, sendika ve konfederasyonları ifade eder. Disiplin kurulu, Sendikalar ve Toplu İş Sözleşmesi Kanununda kuruluşların zorunlu organları arasında sayılmıştır. Kanunda genel kurul dışındaki organlar hakkında detaylı maddeler bulunmamakla beraber bu organlara dair ortak hükümlere ayrı bir madde başlığı altında yer verilmiştir. Dolayısıyla sendikalarda disiplin kurulunun görev ve yetkilerinin daha ziyade uygulama ve içtihatlarla geliştiği söylenebilir. Çalışmada öncelikle 6356 sayılı Kanuna göre sendikalardaki disiplin kurulları hakkında genel bilgi verilmiştir. Bu kısımda, disiplin kurullarının oluşumu, kurul üyeliği, kurulun görevleri, işleyişi ve kurul kararlarına karşı itiraz mekanizması değerlendirilmiştir. İkinci kısımdaysa sendika disiplin uygulamalarına yönelik bazı Yargıtay kararları incelenmiştir.

Anahtar Kelimeler: toplu iş hukuku, sendika, konfederasyon, sendika organları, disiplin.

\section{SUMMARY}

Discipline is the condition of a community that meticulously and diligently abides by its laws and its written or unwritten rules regarding the order. Discipline is necessary for trade union organizations to achieve their goals, as in any organization. Organization means trade unions and confederations. The Disciplinary Board is listed among the mandatory bodies of the organizations in the Trade Unions and Collective Bargaining Code. Although there are no detailed articles about organs except the general assembly, common provisions regarding these organs are included under a separate article title. Therefore, it can be said that the duties and powers of the disciplinary board in trade unions are rather developed with practice and case law. In the study, firstly, general information about the disciplinary boards in

Bu makale Etik Kurul İznine tabi değildir.

* Dr. Öğr. Üyesi, Marmara Üniversitesi, umit.orhan@marmara.edu.tr, https://orcid.org/00000001-7981-782X. 
IIIIIIIIII -

trade unions in terms of Code No.6356 was given. In this section, the formation of disciplinary boards, membership, their duties, process and the mechanism of objection against their decisions are evaluated. In the second part, some Supreme Court decisions regarding trade union discipline practices are examined.

Key words: collective labor law, trade union, confederation, organs of trade union, discipline

\section{GíRIŞ}

Kişilerin, içinde yaşadıkları topluluğun genel düşünce ve davranışlarına uymalarını sağlamak amacıyla alınan önlemlerin bütününe disiplin denir ${ }^{1}$. Sendikaların da diğer tüm teşekküllerde olduğu gibi, amaçlarına ulaşabilmeleri için bir disiplin organizasyonlarının olması gerekmektedir

Sendikal disiplinin temelinde, "sendika düzenine uyma borcu" yatmaktadır ki öğretiye göre, bu borç, sendika üyesinin sendikaya karşı yükümlülükleri arasındadır ${ }^{2}$. Sendika üyeleri sendika tüzüğüne ve disiplinine riayet etmelerinin yanında, sendikanın düzenini bozacak, sendikanın faaliyetlerini olumsuz etkileyecek tüm davranışlardan kaçınmakla yükümlüdürler.

6356 sayılı Sendikalar ve Toplu İş Sözleşmesi Kanunu’na (STISK)³ göre kuruluş, sendika ve konfederasyonları ifade eder. Kuruluşların ve şubelerinin organlar1; genel kurul, yönetim kurulu, denetleme kurulu ve disiplin kuruludur $(\mathrm{m} .9 / 1,1)^{4} .274$ say1l Kanun $^{5}$ döneminde zorunlu organlar arasında say1mayan disiplin kuruluna 2821 say1l Kanunda ${ }^{6}$ zorunlu organlar arasında yer verilmiştir 7 . Hatta 2821 sayılı Kanun'da disiplin kurulu ayrı bir madde ile düzenlenmiştir. Ancak 6356 sayılı Kanun'da genel kurul dişındaki organlar ayrı maddeler hâlinde düzenlenmemiş, bu organlara dair ortak hükümlere ayrı bir maddede yer verilmiştir. Dolayısıyla sendikalarda disiplin kurulunun görev ve yetkilerinin daha ziyade uygulama ve içtihatlarla geliştiği söylenebilir.

Türk Dil Kurumu, https://sozluk.gov.tr/ Erişim Tarihi: 26.10.2020.

2 Nuri Çelik, Nurşen Caniklioğlu ve Talat Canbolat, İş Hukuku Dersleri (31.Bası, Beta 2018) 830; Fevzi Şahlanan, Toplu Işs Hukuku (1.Bası, On İki Levha 2020) 191; A. Can Tuncay ve F. Burcu Savaş Kutsal, Toplu Işs Hukuku (5. Bas1, Beta 2016) 100; Ercan Akyiğit, Toplu İs Hukuku (2.Bası, Seçkin 2020) 246; Melda Sur, İş Hukuku Toplu İlişkiler (6.Bası, Turhan 2017) 145; Ömer Ekmekçi, Toplu İş Hukuku Dersleri (2.Bası, On İki Levha 2019) 102.

3 Sendikalar ve Toplu İş Sözleşmesi Kanunu, Kanun Numarası: 6356, Kabul Tarihi: 18.10.2012, RG 07.11.2012/28460.

4 Disiplin Kurulları hakkında genel bilgi için bkz. Şahlanan (n 3) 166-171; Tuncay ve Savaş Kutsal (n 3) 86-88; Sur (n 3) 134 - 136; Ekmekçi (n 3) 92-93; Çelik vd. (n 1) 850.

5 Sendikalar Kanunu, Kanun Numaras1: 274, Kabul Tarihi: 15.07.1963, RG 24.07.1963/11462.

6 Sendikalar Kanunu, Kanun Numaras1:2821, Kabul Tarihi: 05.05.1983, RG 07.05.1983/18040.

7 Tuncay ve Savaş Kutsal (n 3) 86.

8 Disiplin kurulu: Madde 18 - (1) Disiplin kurulu en az üç en çok beş üyeden oluşur. (2) Disiplin kurulu, sendika veya konfederasyonun tüzüğüne, amaç ve ilkelerine aykır hareket ettiği ileri sürülen üyeleri hakkında soruşturma yapar, üyelikten çıkarma dışındaki tüzügü̈nde gösterilen disiplin cezalarını verir ve sonucunu genel kurula ve diğer ilgililere bildirir. (3) Disiplin kurulu toplantıları hakkında yönetim kuruluna ilişkin 17 'nci madde hükmü uygulanır. 
Çalışmamızda, öncelikle STISSK'e göre sendika disiplin kurullarının oluşumu, kurul üyeliği, kurulun görevleri, işleyişi ile kurul kararlarına karş1 itiraz mekanizması hakkında genel bilgi verilecek, ardından sendikalarda disiplin uygulamalarına yönelik bazı Yargıtay kararları incelenecektir.

\section{Kuruluşlardaki Disiplin Kurulları}

\subsection{Disiplin Kurulunun Oluşumu ve Disiplin Kurulu Üyeliği}

Disiplin kurulu, kuruluşlarda zorunlu organlardandır. Kuruluşlar, ihtiyaca göre başka organlar da kurabilir. Ancak genel kurul ile yönetim, denetim ve disiplin kurullarının görev ve yetkileri bu organlara devredilemez (m.9/2)9. Örneğin yönetim kurulu veya herhangi bir ihtiyari kurul, bir disiplin ihlalini hiçbir şekilde kendisi soruşturamaz ve bir disiplin yaptırımına hükmedemez ${ }^{10}$. Ancak kanaatimizce bizzat disiplin kurulu tarafindan, kendi üyeleri arasından veya dışından bir ön soruşturmacı ya da rapor yazıcı görevlendirilmesi bu ilkeyle çelişmez. Nihayetinde ilgili işlemler disiplin kurulu adına ve bu kurulca seçilen kişi veya kişiler tarafından gerçekleştirilmektedir ve karar merci değişmemektedir.

Organlarla ilgili ortak hükümlere göre, genel kurul dışındaki zorunlu organların dolayısıyla disiplin kurulunun da üye sayısı üçten az dokuzdan fazla ve şubelerin disiplin kurullarının üye sayıları üçten az beşten fazla olamaz $^{11}$. Bu kurullara as1 üye sayısı kadar yedek üye seçilir (m.9/1, 2. ve 3. cümle). Kanunda geçen "Bu organlardan genel kurul dışında kalanların üye sayıları üçten az dokuzdan fazla; konfederasyonların yönetim kurullarının üye sayıları beşten az yirmi ikiden fazla ve şubelerin genel kurul dışındaki kurullarının üye sayıları üçten az beşten fazla olamaz." cümlesinin

94688 sayılı Kamu Görevlileri Sendikaları ve Toplu Sözleşme Kanununda (KGSTSK) bu konuda farklı bir esas benimsenmiştir. Sendika ve konfederasyonlar, zorunlu organların dışında da organlar kurabilir. Tüzüklerinde belirtilmesi kaydıyla genel kurul dışındaki organlar, görev, yetki ve sorumluluklarını kurulacak bu organlara devredebilir (m.8/2).

10 Yargitay 9 HD, 985/3647, 08.02.2005: “Merkez yönetim kulununun davacıyı şube yönetim kurulu görevinden ve şube başkan yardımcılığ görevinden alınması için genel disiplin kuruluna sevk etme yerine disiplin kurulu yetkilerini kullanarak davactyı şube başkan vekili görevinden almast yasa, tüzük hükümlerine aykırı bulunduğundan, davanın kabulü gerekirken yazılı şekilde reddetmesi hatalı olup bozmayı gerektirmiştir."

1 Bkz. Banu Uçkan, "Türkiye'de Kamu Görevliliği Sendikacılığı” (1.Bası, Legal 2013) 56: "4688 sayılı Kanun zorunlu organların oluşması için gerekli olan en az ve en fazla kişi sayısını belirlemekte, ancak bunların görev ve yetkileri ile toplantı ve karar alma usulleri için 6356 say1lı Kanuna göndermede bulunmaktadır (md.13/III)...Disiplin kurulu en az 3, en çok 5 üyeden... oluşmaktadır. Atıfta bulunulan 6356 sayılı Kanuna göre sendika ve konfederasyonların tüzüklerinde daha yüksek bir yeter sayı öngörülmemişse, yönetim, denetleme ve disiplin kurulları için toplantı yeter sayısı kurul üye sayısının salt çoğunluğu, karar yeter sayısı ise toplantıya katılanların salt çoğunluğudur (md.9/7)." 
IIIIIIIIIII

Anayasaya aykırı olduğu gerekçesiyle iptali için Anayasa Mahkemesine başvurulmuş, mahkeme talebi reddetmiştir ${ }^{12}$.

Disiplin kuruluna üye seçimi genel kurulda, yargı gözetimi altında serbest, eşit, gizli oy, açık sayım ve döküm esasına ve tüzük hükümlerine göre yapılır (m.14/1). Yönetim, denetim ve disiplin kuruluna seçilebilmek için STİSK'nin 6'ncı maddesinde aranan şartlara sahip olmak gerekir. Bu şartlar; fiil ehliyetine sahip ve fiilen çalışan gerçek veya tüzel kişi olmak ve Kanunda sayılan bazı suçlardan mahkûmiyeti olmamaktadır ${ }^{13}$. Bu şartlara sahip olmayan birinin seçildiğini tespit eden valiliğin veya Bakanlığın başvurusu üzerine mahkeme, bu kişinin görevine son verir. Mahkemenin kararı kesindir (m.9/3). Kurul üyesinin kurul üyeliği sırasında sayılan suçlardan mahkûmiyetine karar verilmesi halinde de kurul üyeliği kendiliğinden sona erer (m.9/5).

Kuruluş ve şube yönetim, denetleme ve disiplin kurulu üyelerinin görevleri, milletvekili veya belediye başkanı seçilmeleri hâlinde kendiliğinden son bulur (m.9/6). Sendikaların kuruluş amacının, işçi veya memur olduğuna bakılmaksızın, bu kuruluşlara üye olanların menfaatlerini gözetmek olduğu dikkate alındığında, ilgili kurullarda görev alan kişilerin siyasetten bağımsızlıklarını sağlamanın isabetli olduğu kanaatindeyiz.

Öğretide bizim de katıldığımız üzere, söz konusu kural ile birlikte iki görevin birlikte yürütülmesinin yol açabileceği sakıncaların önlenebileceği, sendikanın siyasi otoriteye karşı bağımsızlığının sağlanabileceği ifade edilmektedir ${ }^{14}$.

$\mathrm{Bu}$ tür yasaklar kamu görevlileri için mevcuttur ${ }^{15}$. Milletvekili ve mahalli idare seçimlerine katılan kamu görevlilerinin seçimden belli bir süre önce görevlerinden çekilmeleri öngörülmekle, kamu görevlisi statüsünden yararlanmaları, diğer adaylar karşısında avantajlı konuma gelmeleri, seçmenler üzerinde kendi yararlarına bir durum sağlamaları, sahip oldukları yetkileri

12 “Anayasa'nın 51. maddesinin üçüncü fikrasında "Sendika kurma hakkının kullanılmasında uygulanacak şekil, şart ve usuller kanunda gösterilir.” denilmiştir. Buna göre kanun koyucu, Anayasa'da yer alan sendikal hakların sinırlandırılması kurallarına bağlı kalmak şartıyla, sendika kurma hakkının kullanılması ile ilgili olarak kuruluş organlarının üye sayısının alt ve üst sinırını düzenleme konusunda takdir yetkisine sahiptir. Kanun koyucunun Anayasa'ya aykırl olmamak kaydlyla takdir yetkisi kapsamında getirdiği düzenlemelerin yerinde olup olmadı̆̆ hususu ise anayasallık denetiminin kapsamı dışındadır." (Anayasa Mahkemesi, 1/161, 22.10.2014, RG, 11.11.2015/29529).

13 Ancak 26/9/2004 tarihli ve 5237 sayılı Türk Ceza Kanununun 53 üncü maddesinde belirtilen süreler geçmiş olsa bile; zimmet, irtikâp, rüşvet, hırsızlık, dolandırıcılık, sahtecilik, güveni kötüye kullanma, hileli iflas, ihaleye fesat karıştırma, edimin ifasına fesat karıştırma, suçtan kaynaklanan mal varlığı değerlerini aklama ve kaçakçılık suçlarından birinden mahkûmiyeti bulunanlar sendika kurucusu olamaz.

14 Sur (n 3) 125.

15 Bkz. Milletvekili Seçimi Kanunu, Kanun Numarası: 2839, Kabul Tarihi: 10.06.1983, RG, 13.06.1983/18076 ve Mahalli İdareler ile Mahalle Muhtarlıkları ve İhtiyar Heyetleri Seçimi Hakkında Kanun, Kanun Numarası: 2972, Kabul Tarihi: 18.01.1984, RG, 18.01.1984/18285. 
kişisel çıkarları yönünde kullanmaları önlenmek istenmiştiri ${ }^{16}$. Kamu görevi statüsünden kaynaklanan idari gücün oy temini için siyasi bir güç olarak kullanılması önlenmeye çalışılmıştır ${ }^{17}$. Sendikalar kamu tüzel kişisi olmadığ1 gibi, organlarda görev alan kişiler de kamu görevlisi değildirler. Ancak yine de genel kurulda kamu görevi statüsünden kaynaklanan idari gücün oy temini için siyasi bir güç olarak kullanılması söz konusu olabilir. Şunu da eklemek gerekir ki milletvekilli veya belediye başkanı seçilme, siyasetin içinde yer almanın sadece bir boyutudur. Yoksa siyasi partinin yönetim organı üyesi olmak ya da faaliyetlerinde aktif olarak yer almak zorunlu organlara üyeliğe engel değildir ${ }^{18}$.

Disiplin kurulu üyeliği ücret karşıllğında ya da ücret almadan yapılabilir. Disiplin kurulu üyelerine verilecek ücret, tazminat, ödenek ve yolluklar ile sosyal hakların belirlenmesi görevi ise sendika genel kuruluna aittir (m.11/1-f). Sendika yönetim kurulu ya da disiplin kurulu kendilerine resen bir ücret miktarı takdir edip uygulayamaz.

Sendikalar ve Toplu İş Sözleşmesi Kanununa göre yönetici, kuruluşun ve şubesinin yönetim kurulu üyelerini ifade etmektedir (m.2/1-i). Dolayısıyla yönetim kurulu üyeleri dışında kalan disiplin kurulu üyeleri STISK açısından profesyonel sendika yöneticisi sayılmaz ve Kanunda yer alan sendika yöneticilerine tanınan haklardan ve korumalardan yararlanamazlar.

Disiplin kurulu üyeleri, yönetim ve denetim kurulu üyeleriyle bu sıfatla kendi genel kurullarına delege olarak katılır (m.10/1) ${ }^{19} .2821$ sayılı Sendikalar Kanununda benzer hüküm, "Konfederasyon, sendika ve sendika şubesi yönetim ve denetleme kurulu üyeleri bu sifatla kendi genel kurullarına delege olarak katılırlar" şeklindeydi (2821, m.10/5). Görüldüğü üzere 2821 sayıl1 Kanunda doğal delege olarak sayılmayan disiplin kurulu üyeleri de 6356 sayılı Kanun ile bu sıfatın sahibi olmuşlardır. 2128 sayılı Kanunda var olan hükmün gerekçesinde, yönetim ve denetim kurulu üyelerinin genel kurulda

16 Cemil Kaya, 'Milletvekili ve Mahalli İdare Seçimlerine Katılan Kamu Görevlilerinin Görevden Çekilmesi ve Göreve Dönmesi’ (2004) C. 13 (Sa. 1) Çağdaş Yerel Yönetimler Dergisi, https://dergipark.org.tr/tr/download/article-file/789851 Erişim Tarihi 10.03.2021; Erdal Abdulhakimoğulları ve Burcu Erdinç, 'Kamu Görevlilerinin Milletvekilliği Seçimlerine Katılmak Üzere Görevden Çekilmeleri ve Göreve Dönmeleri’ (2015) C. XIX, Sa. 4, Gazi Üniversitesi Hukuk Fakültesi Dergisi 227, 236.

17 Kaya (n 17) 274.

18 Tuncay ve Savaş Kutsal (n 3 ) 73.

19 KGSTSK'e göre, "Sendika şubeleri ile sendika ve konfederasyonların yönetim ve denetleme kurulu üyeleri bu sıfatla kendi genel kurullarına delege olarak katılırlar (m.9/5)."

KGSTSK. m. 9/5'de, doğal delegelik esasına yer verilmiş ancak yönetim ve denetleme kurulu üyeleri sayılmasına karşın, 6356 sayılı Kanundan farklı olarak disiplin kurulu üyeleri tıpkı 2821 sayılı Kanunda olduğu gibi doğal delege olarak sayılmamıştır (Bkz. Hatice Duygu Özer, 'İşçi Sendikalarında Delegelik' (2020) Temmuz, C:11, S:2, Çalışma İlişkileri Dergisi, 22, 29). 
IIIIIIIIII

bu surette sorumlu bulundukları dönemin hesabını verebilmeleri sağlandığı belirtilmiştir $^{20}$. Öğretide doğal delegelerin sayısı sendika içi demokrasi açısından eleştirilmektedir ${ }^{21}$. Biz de bu görüşlere katılıyoruz.

Sosyal Güvenlik Kurumu'ndan (SGK) yaşlılık veya malullük aylığı ya da toptan ödeme alarak işten ayrılan iş̧̧ilerin sendika üyeliği sona erer. Ancak Kanunda bazı gruplar için bir istisna oluşturulmuştur. Buna göre SGK'den yaşl1lık veya malullük aylığ 1 ya da toptan ödeme alarak işten ayrılan işçilerden çalışmaya devam edenler ile kuruluş ve şubelerinin yönetim, denetleme ve disiplin kurullarındaki görevleri sırasında yaşlılık veya malullük aylığı ya da toptan ödeme alanların üyeliği, görevleri süresince ve yeniden seçildikleri sürece devam eder (m.19/6).

\subsection{Disiplin Kurulunun Görevleri ve İşleyişi}

Disiplin kurulu, sendika içi disiplini sağlayan ve denetleyen, üyeleri üzerinde sendikal otoriteyi temsil eden organd ${ }^{22}$. Kuruluşlarda otoritenin asıl sahibi genel kurullardır. Disiplin kurulu bu otoriteyi sağlama görevini genel kurul adına yürütür ${ }^{23}$.

Disiplin kurulunun görev, yetki ve sorumlulukları kuruluşların tüzüklerinde belirlenir. Bu görevler, sendika tüzügüne, sendika veya konfederasyon amaç ve ilkelerine aykırı hareket ettiği ileri sürülen üyeler hakkında soruşturma yapıp, üyelikten ihraç dışında, disiplin cezaları vermek ve sonucunu genel kurula ve ilgililere bildirmektedir ${ }^{24}$. Üyelikten çıkarma kararını ancak genel kurul karar verebilir (m.19/4). Burada soruşturma yapma ve ihracı teklif yine disiplin kurulunun icra edeceği bir görevdir.

Disiplin kurulu genellikle yönetim kurulunun disipline sevk kararı ile soruşturmaya başlamaktadır. Ancak kuruluşların tüzüklerinde disiplin kurullarının resen soruşturmaya başlayabileceğine yönelik hüküm varsa, kurul resen de soruşturma yapabilecektir. Tüzükte bu yönde bir hüküm bulunmadığ 1 durumlarda, disiplin kurulu haberdar olduğu disiplin ihlallerini

20 https://www.tbmm.gov.tr/tutanaklar/TUTANAK/MGK_/d01/c009/mgk_01009144ss0573. pdf Erişim Tarihi: 12.03.2021.

21 Şahlanan,(n 1) 92-93; Fevzi Şahlanan, '6356 Sayılı Sendikalar ve Toplu İş Sözleşmesi Kanunun Sendikalara İlişkin Hükümlerin Değerlendirilmesi’ (2013) Çalışma ve Toplum, (39), 110, 115; Tuncay ve Kutsal Savaş, (n 1) 61; Ufuk Aydın ve Özlem Keskin, '2821 Sayılı Kanundan 6356 Sayılı Kanuna: Türkiye'de Sendikalar Hukukunun Dönüşümü' (2015) C.1, S.2, Anadolu Üniversitesi Hukuk Fakültesi Dergisi, 1, 27, Mesut Aydın, 'Sendika İçi Demokrasinin Sağlanmasında 6356 Sayılı Sendikalar ve Toplu İş Sözleşmesi Kanununun Yeri' (2016), 4. Sayı, İş ve Hayat Dergisi, 9, 48; Kuvvet Lordoğlu ve Derya Demirdizen, 'Türkiye'de Sendika İçi Demokrasi ya da Bir İmkânsızın Arayışı mı?' (2013) V. Sosyal Haklar Uluslararası Sempozyumu, İstanbul, Petrol İş Yayını, 223, 229.

22 Tuncay ve Kutsal Savaş (n 3$) 86$.

23 ibid 86; Sur (n 3) 134-135; Akyiğit (n 3) 197.

24 Sur (n 3)134; Çelik, Caniklioğlu ve Canbolat (n 3) 850. 
ihbar mahiyetinde yönetim kuruluna bildirmeli, yönetim kurulunca sevke karar verilirse soruşturmayı başlatmalıdır.

Genel kurul dışında kalan organlar, bu organların oluşumu, görev, yetki ve sorumlulukları, çalışma usul ve esasları ile toplantı ve karar yeter sayılarının kuruluşun tüzüğünde yer alması, Kanunda zorunlu hususlar arasında sayılmıştır (m.8/1,f). Buna göre de tüzükte daha yüksek bir yeter sayı öngörülmemişse, disiplin kurulu için; toplantı yeter sayısı kurul üye sayısının salt çoğunluğu, karar yeter sayısı toplantıya katılanların salt çoğunluğudur (m.9/7). Oyların eşitliği durumunda kurul başkanının ya da başkan vekilinin oyunun üstün sayılmasına tüzükte yer verilebilir ki zaten çoğu sendika tüzüklerinde bu yönde hükümlere rastlanmaktadır. Örneğin üç veya beş kişiden oluşan bir disiplin kurulunda bir üyenin yokluğu durumunda kalan üyelerin farklı karar vermesi durumunda bu tüzük hükmü uygulanabilir.

Sendikalar ve Toplu İş Sözleşmesi Kanunu'nda disiplin ihlallerinin ve yaptırımlarının neler olduğuna ve bu yaptırımların nasıl uygulanacağına dair bir hüküm yoktur. Bu sebeple söz konusu ihlaller ve yaptırımlar farklı türde olabilir. Ancak bu yaptırımların uygulanabilmeleri için ihlallerin ve yaptırımların kuruluşun tüzüğünde yer alması gerekir. Uygulamada kuruluşlar, disipline dair hükümlerini ayrı bir düzenleme (iç yönetmelik) ile tertip etmektedirler. Çoğu sendika bunu "disiplin yönetmeliği”" şeklinde adlandırmaktadır. Ancak bunların Anayasa m.124'te yer alan ve normlar hiyerarşisinde Cumhurbaşkanlığ Kararnamesinin altında yer alan yönetmelikle aynı hukuki nitelikte olmadığını belirtmek gerekir ${ }^{25}$. İhlal ve yaptırımların tüzükte yer alması gerekir. Anılan yaptırımlar, "uyarı", "kınama", "tavsiye" ya da "işsizlik ödeneğinden yoksun bırakma", "üyeliği geçici olarak askıya alma", "sendika üyeliğinden çıkarma", "verilen cezanın sendikal basında yer alması" şeklinde olabilir26.

Anayasa'nın sendika ve üst kuruluşlarının tüzükleri, yönetim ve işleyişleri, Cumhuriyetin temel niteliklerine ve demokrasi esaslarına aykırı olamaz hükmü gereği (m.51/6), sendikaların işleyişlerinin demokratik esaslara uygun olması esası benimsenmiştir. Disiplin yargılaması demokratik esaslara uygun olmalı, keyfi uygulamalara izin vermemelidir. Disiplin ihlalleri ve bunlara verilecek cezalar tüzükte düzenlenmeli, ihlali gerçekleştiren kişinin kendini savunması imkânı mutlaka verilmelidir. Disiplin hükümlerinin bu hususlara uygunluğu esasen herhangi bir kurum tarafindan önceden denetlenmemektedir. Sendika ve konfederasyonların kuruluşu sırasında yetkili makamlarca yapılan denetim esasen tüzüğün veya ilgili maddede sayılan belgelerin içerdikleri bilgilerin

25 Anayasa m.124: (1) Cumhurbaşkanı, bakanlıklar ve kamu tüzelkişileri, kendi görev alanlarını ilgilendiren kanunların ve Cumhurbaşkanlı̆̆ kararnamelerinin uygulanmasını sağlamak üzere ve bunlara aykırı olmamak şartıyla, yönetmelikler çıkarabilirler. (2) Hangi yönetmeliklerin Resmî Gazetede yayımlanacağı kanunda belirtilir.

26 Aydin M (n 22) 48. 
IIIIIIIIII!

kanuna aykırılı̆̆ının tespit edilmesi ya da Kanunda öngörülen kuruluş şartlarının sağlanıp sağlanmadığına ilişkindir. Mesela kuruluşların tüzüğünde "genel kurul dişında kalan organlar, bu organların oluşumu, görev, yetki ve sorumlulukları, çalı̧̧ma usul ve esasları ile toplantı ve karar yeter sayları"nın varlığı aranır yoksa içerik denetimi yapılarak muğlak veya demokratik esaslara aykırı disiplin hükümlerinin ayıklanması amaçlanmaz. Ayrıca disipline yönelik iç yönetmelik, kuruluş aşamasından sonraki bir aşamada da gerçekleştirilebilir.

Bazen de sendika yönetimine egemen olanlar, ellerinde tuttukları disiplin yetkisiyle, kendi yönetimleri hakkında eleştiride bulunan ya da kendilerine rakip olarak gördükleri üyeleri cezalandırmak isteyebilmektedir ${ }^{27}$. Çoğu kuruluşun tüzüğ̈̈ ve disiplin talimatı incelendiğinde, ihlal türü olarak "ortak menfaate aykırı hareket etme" gibi muğlak kalıplara sıkça rastlanılmaktadır. Disiplin uygulamalarının yerindeliğini denetlemede ölçüt, "ortak sendikal çıkarları korumak ve geliştirmek" olmalı, özellikle tüzüğün yetersiz olduğu durumlarda yapılacak yorumlarda bu ilke göz önünde tutulmalıdır ${ }^{28}$.

Öğretide, hakkaniyet kurallarına göre bir üyenin artık sendikada kalmasının istenemeyeceği derecede haklı nedenlerin ortaya çıkması halinde, bu nedenler tüzükte çıkarılma nedeni olarak sayılmasa da, genel kurulun Türk Medeni Kanunu m.67/3'e göre üyeyi sendikadan çıkarabileceği kabul edilmektedir²9.

Kanunda sendikaların tutacakları defter ve kayıtları ayrı bir madde ile düzenlenmiştir (m.30). Buna göre genel kurul, yönetim kurulu, denetleme kurulu ve disiplin kurulu "karar defterleri" tutulmak zorundadır. Sendika ve Konfederasyonların Denetim Esasları ve Tutacakları Defterler ile Toplu İş Sözleşmesi Sicili Hakkında Yönetmelik ${ }^{30}$ hükümlerine göre genel kurul, yönetim kurulu, denetleme kurulu ve disiplin kurulu kararları defterlere en geç bir hafta içinde yazılır. Genel kurul kararları divan üyelerince iki gün içinde, diğer kurul kararları ise gelecek ilk toplantı zamanı aşılmamak üzere en geç bir ay içinde katılan üyelerce imzalanır (Yön.m.12/1 ve 2). Tutulan bu defter ve kayitlar, 04.01.1961 tarihli ve 213 sayılı Vergi Usul Kanununa göre demirbaş sınıfına giren her türlü eşya veya malzeme demirbaş defterine kaydedilir (Yön.m.11/1,son).

\subsection{Disiplin Kurulu Kararlarına İtiraz}

Kuruluşlarda organ seçimlerinde yönetime talip olan adaylar genelde tüm kurullar için aday göstermektedir. Yani seçimi kazanan yönetimin belirlediği kurullar görev başı yapmaktadır. Dolayısıyla yönetimde egemen olan grubun,

27 Şahlanan (n 3) 168.

28 Ibid 169.

29 Turhan Esener ve Yeliz Bozkurt Gümrükçüoğlu, Sendika Hukuku (2. Bası, Vedat Kitapçıllk 2017) 199; Haluk Hadi Sümer, İş Hukuku Uygulamaları (7. Bas1, Seçkin 2019) 503.

$30 \quad$ RG, 26.11.2013/28833. 
kurullara da hâkim olduğu söylenebilir. Bu durumdaysa kurul kararlarına karş1 itiraz yolu önem kazanmaktadır.

Disiplin kurulu kararlarına karşı itiraza ilişkin STİSK'de herhangi bir hüküm yer almamaktadır. STİSK m.80'e göre, kuruluşlar hakkında, 6356 sayılı Kanunda hüküm bulunmayan hâllerde Türk Medeni Kanunu ile Dernekler Kanununun 6356 sayılı Kanuna aykırı olmayan hükümleri uygulanır. Dernekler Kanunda da bu konuya ilişkin bir hüküm yoktur. Dernekler Kanunu m.36 ${ }^{31}$ 'nın göndermesiyle Türk Medeni Kanununa bakıldığında, dernek kurullarıyla ilgili olarak yalnızca genel kurulun kararının iptali düzenlenmiş, genel kurul dışındaki diğer organların kararlarına karşı, dernek içi denetim yolları tüketilmedikçe iptal davası açılamayacağı belirtilmiştir ${ }^{32}$. Bu durumda kuruluşlarda disiplin kurulu kararına karşı itirazın, uygulamaya ve içtihatlara bırakıldığ söylenebilir.

Yukarıda ifade edildiği üzere kuruluşlarda disiplin hükümleri tüzükle veya tüzükten ayrı bir iç yönetmelikle düzenlenebilmektedir. Bazen disiplin kurulu kararlarına karşı, örgüt içi itiraz yollarına da bu düzenlemelerde yer verilmektedir. Örneğin bazı kuruluş tüzüklerine göre, şube disiplin kurulu kararına karşı genel disiplin kurulunda veya disiplin kurulu kararına karşı yönetim kuruluna itiraz edilebilmektedir ${ }^{33}$. Bu açıdan kuruluş tüzüğünün ve disiplin düzenlemelerinin içerikleri önemlidir. Çünkü olası bir uyuşmazlıkta hâkim de evvela kuruluşun iç düzenlemelerine bakacaktır.

Disiplin kurulu kararlarına karşı itiraz konusunda esasen ikili bir ayrım yapmak yerinde olacaktır. Birincisi üyelikten çıkarmaya yönelik disiplin kurulu kararına itiraz ${ }^{34}$ ve ikincisi de üyelikten çıkarma dışındaki disiplin kurulu kararlarına itirazdır. Her durumda TMK m.83/2'nin, “diğer organların kararlarına karşı, dernek içi denetim yolları tüketilmedikçe iptal davası açılamaz" hükmünün gözetilmesi gerekir.

Üyelikten çıkarma cezasını ancak genel kurul verebilir (m.19/4). Kanunun

31 Dernekler Kanunu m.36/son cümle: “Bu Kanunda hüküm bulunmayan hallerde 4721 sayılı Türk Medeni Kanununun hükümleri uygulanır."

32 Türk Medeni Kanunu, m.83, "Kararın iptali": (1) Toplantıda hazır bulunan ve kanuna veya tüzüğe aykırı olarak alınan genel kurul kararlarına katılmayan her üye, karar tarihinden başlayarak bir ay içinde; toplantıda hazır bulunmayan her üye karart öğrenmesinden başlayarak bir ay içinde ve her hâlde karar tarihinden başlayarak üç ay içinde mahkemeye başvurmak suretiyle kararın iptalini isteyebilir. (2) Diğer organların kararlarına karşı, dernek içi denetim yolları tüketilmedikçe iptal davası açılamaz. (3) Genel kurul kararlarının yok veya mutlak butlanla hükümsüz sayıld $\breve{g}$ l durumlar saklıdır.

33 Örneğin bkz. Eğitim-Sen Disiplin Kurulları Yönetmeliği https://egitimsen.org.tr/disiplinkurullari-yonetmeligi/; Türkiye Genel Hizmetler İşçileri Sendikası tüzüğü https:// www.genel-is.org.tr/tuzuk,2,10980\#.YGrdmegzZPY; Büro Memurları Sendikası http:// buromemursen.org.tr/icerik/disiplin-kurulu-yonetmeligi/ (Erişim tarihi: 05.04.2021)

34 Üyelikten çıkarma kararı genel kurul tarafından verilse de, disiplin kurulunun bu yönde kararı gereklidir. Burada kastedilen bu karardır. 
IIIIIIIIII

açık hükmü dolayısıyla soruşturmayı gerçekleştiren disiplin kurulu çıkarma kararı verdiğinde, esas itiraz makamı genel kuruldur. Örgüt içi yollar tüketildiği zaman genel kurul kararına karşı mahkemeye başvurulabilecektir ${ }^{35}$.

Üyelikten çıkarma dışındaki herhangi bir ceza durumunda ise kuruluş tüzüğündeki hükümlere bakılması gerekir. Kanaatimizce tüzükte disiplin kurulunun çıkarma cezası dışında vereceği kararlara karşı bir itiraz mekanizması göstertilmişse (mesela yönetim kuruluna itiraz) evvela bu yollar tüketilmelidir ${ }^{36}$. Ondan sonra mahkemeye başvurulabiliir ${ }^{37}$. Hatta Yargıtay, disiplin kurullarının üyeler hakkında verdiği geçici (tedbiren) uzaklaştırma kararlarının iptaline yönelik kararlar vermiştir ${ }^{38}$. Acaba bu konuda kuruluş tüzüğünde herhangi bir hüküm yoksa bu durumu nasıl yorumlamak gerekir? Kanunda, Dernekler Kanununa atıf olduğu için dernek disiplinine yönelik Yargitay kararları bu hususta yol gösterici olabilir. Yargitay Hukuk Genel Kurulu, dernek disiplin kurulunun kararına karşı mahkemeye yapılan itirazla ilgili bir uyuşmazlıkta "Tüzükte hüküm bulunmayan hallerde en son başvurulacak organ genel kuruldur " prensibini benimsemiştir ve yerel mahkemenin aksi yöndeki kararını bozmuştur ${ }^{39}$. Öğretide kararı eleştiren Engin'e göre, dava konusu olayda, geçici

35 Sur (n 3) 135.

36 Yargitay 18. HD, 26.06.2012, E. 2012/7041, K. 2012/8107: "Somut olayda; davact, davalı derneğin 22.09.2006 gün ve 2006/317 sayıl yönetim kurulu kararının iptalini istemiştir. Davalı derneğe ait tüzüğe göre, yönetim kurulu kararlarının kesin mahiyette olmadiğ bu kararlara karşı genel kurul nezdinde itiraz imkânı bulunmaktadır. Genel kurulun onayı olmayan yönetim veya disiplin kurulu kararları, derneğin iç denetim yolları tüketilmis kararlarl olarak kabul edilemez. Özellikle dernek üyeliğine kabul ve üyelikten ihraç hallerinde, son karar 4721 sayll Türk Medeni Kanunu'nun 80. maddesine göre de genel kurula aittir. Dernek genel kurulunun dernek üyeliğinden ihraca ilişkin bir kararı bulunmadıkça, dernek üyeliğinin devam edeceği de açıktır. Şu halde, davacının üyelikten ihracına dair genel kurulda alınmış bir karar bulunmadığı, davacının dernek iç denetim yollarını tüketmediği anlaşıldığından, mahkemece dava şartının gerçekleşmediği gerekçesiyle davanın reddine karar verilmesi gerekirken, yerinde olmayan gerekçeyle kabulü doğru görülmemiştir"; Benzer yönde bkz. Yargitay 2. HD, 01.11.2007, E. 2007/5059, K. 2007/14643: Dernek tüzüğ̈̈nün 66. maddesinde "Disiplin Kurulunca verilen bir ylla kadar geçici çıkarma cezalarına ilişkin kararın kesin olduğu, hiçbir itiraz merciinin bulunmadı̆̆ belirtilmektedir. Tüzükte yer alan bu hüküm, disiplin kurulunca verilen bir yıla kadar geçici çıkarma kararlarına karşı, dernek içi denetim yollarını kapatmıştır. Davacının, tüzük hükümlerine göre, kendisi hakkındaki geçici çıkarma kararını, derneğin en yetkili karar organı olan genel kurula ( TMK m. 73 ) taşıma olanağı bulunmamaktadır. Bu durumda davacıya, yargı organına başvurma olanağ 1 tanımamak, Türkiye Cumhuriyeti Anayasasının 36. maddesinde yer alan hak arama hürriyetinin ihlali sonucunu doğurur. O halde, işin esasının incelenmesi gerekirken yazılı gerekçe ile isteğin reddi doğru bulunmamıştır. (Kazanc1, 22.10.2020).

37 Tuncay ve Kutsal Savaş (n 3$) 87$.

38 Bkz. "1.4.2.1. Ölçülülük İlkesine Uygunluk Açısından Değerlendirilen Karar:" başlığı.

39 Yargitay HGK, 2-300/385, 8.5.2002, Ayn1 yönde Yargitay 2 HD, 11337/12421, 25.10.2004, Yargitay $2 \mathrm{HD}, 642 / 2753,6.2 .2007$. 
ihraç kararına karşı (üyelikten ihraç dışında bir karar olduğu için) dernek içi itiraz yolu öngörülmüş olmadığına göre kesin nitelikteki bu karar karşı iptal davas1 açılması mümkündür. Biz de Ergin'in görüşüne katılmaktayı ${ }^{40}$. Bu görüşle birlikte konuyu sendikalar açısından değerlendirince de şu sonuca varmaktayız: Disiplin kurulunca üyelikten çıkarılma dışında verilen cezalanın kesin olacağına ilişkin (açık) bir tüzük hükmünün bulunmayışından, disiplin kurulu kararının genel kurulun denetimine tâbi olduğu, her konuda mutlaka önce genel kurula başvurup genel kurul kararının alınması ve ancak bu karara karşı iptal davası açılabileceği anlamı çıkartılamaz. TMK m.83 ile de ifade edilen prensibin anlamı, kararı veren organın bu kararına karşı tüzükte kuruluş içi denetim yolu öngörülmüssse bu yolun tüketilmesinden önce uyuşmazlığın yargıya intikal ettirilerek kuruluş dışına çıkartılamamasıdır. Sonuç olarak üyelikten çıkarma dışındaki herhangi bir ceza durumunda şayet tüzükte başkaca bir itiraz yolundan bahsedilmemişse bu karar nihai sayılmalı ve iptali için mahkemeye başvurulabilmelidir.

Yönetim kurulunun, disiplin kuruluna sevk kararına itiraz mümkün müdür? Bunun mümkün olmadığı kanaatindeyiz. Çünkü sevk kararı, disiplin kurulunun soruşturma yapıp karar vermesiyle hukuki değere kavuşur. Sadece disiplin kuruluna sevk kararı, sendika üyesinin hak veya menfaatlerini zedelemiş, hukuki sonuçlarını doğurmuş, tamamlanmış bir işlem değildir.

Yönetim kurulu, disiplin kurulunun ceza verilmesine yer olmadığına dair kararına karşı yargı yoluna başvurabilir mi? Gerçekten de bu kurulların birlikte seçilmiş olması, disiplin kurulunun her sevkte mutlaka yönetim kurulunun sevk ettiği kişilere ceza vereceği anlamına gelmez. Böyle bir ihtimalde de şayet disiplin kurulu üyeyi çıkarma sevkiyle yargılamışsa ve yaptırım uygulamamaya karar vermişse, yönetim kurulu konunun görüşüleceği genel kurulda itirazlarını yapabilir ve genel kurul kararını yargıya taşıyabilir. Üyelikten çıkarma dışındaki sevklerle ilgili, yargılama yapılmış ve disiplin kurulu herhangi bir yaptırım uygulanmaması yönünde karar vermişse bu defa yönetim kurulu, genel kurul beklenmeden karara karşı mahkemeye başvurabilir.

\section{2. İş̧̧i Kuruluşundaki Disiplin Kurulu Kararlarının Yargısal Denetimi}

\subsection{Genel Olarak}

İşçi kuruluşlarında disiplin uygulamalarıyla ilgili uyuşmazlıklarda 7036 sayılı İş Mahkemeleri Kanunu ile getirilen dava şartı olarak arabuluculuğu düzenleyen m.3 uygulanamaz. Arabuluculuk; kanuna, bireysel veya toplu iş sözleşmesine dayanan işçi veya işveren alacağı ve tazminatı ile işe iade

40 Bkz. Baki İlkay Engin, 'Dernek Disiplin Kurulu Tarafından Verilen Geçici İhraç Kararına Karşı İptal Davası Açılamayacağına Dair Yargıtay Hukuk Genel Kurulu Kararının Düşündürdükleri' (2003) C. LXI, S. 1-2, IÜHFM, 277-312. 
IIIIIIIIII

talebiyle açılan davalarda dava şartıdır. Ancak taraflar, aralarında anlaşabilirse bu hususta ihtiyari arabuluculuğa başvurabilir.

Açılacak davaya İMK m.5'e göre, açıldığı tarihte kuruluşun TMK gereğince ikametgâhı sayılan yer mahkemesinde bakılabileceği gibi, işçinin işini yaptığ 1 işyeri için yetkili mahkemede de bakılabilir.

Peki mahkeme incelemeyi nasıl yapmalıdır? Şahlanan'a göre mahkeme önce disiplin uygulamasına neden olan olguların maddi durumunu inceleyecek, tüzükte yazan suçlandırmanın denetimi yapacak ve suça göre cezanın oransallığını inceleyecektir ${ }^{41}$. Örneğin sendika yöneticisine "mana ile bakan" üyenin çıkarılması vb. bir olasılıkta, hakim bunu hafif bir yaptırıma çeviremez ancak karar1 iptal edebilir ${ }^{42}$.

\subsection{Sendika Disiplinine Yönelik Yargıtay Kararları}

\subsection{1. Ölçülü̈lük İlkesine Uygunluk Açısından Değerlendirilen Karar:} Ölçülülük, bir amaca ulaşmak için başvurulan aracın, amacın gerçekleşmesi için elverişli ve gerekli olmasını, ayrıca araç ile amacın ölçüsüz bir ilişki içinde olmamasin 1 ifade eder ${ }^{43}$.

Kuruluşların belirledikleri bazı cezalar istenen amacın ötesinde bir durum yaratabilmektedir. Özellikle geçici uzaklaştırma adı altında bazı disiplin uygulamaları uzun bir süre ilgili üyenin uzaklaştırılmasına sebep olabilmektedir. Genel kurula çok uzun bir zaman olması durumunda geçici uzaklaştırmaların süresi yılları bulabilmektedir. Bir uyuşmazlıkta Yargıtay, 27.03.2009 tarihli Genel Merkez Disiplin Kurulu kararı ile 2008 yılında yapılan sendika genel kurulu sonrasında sendika tüzüğüne göre yeniden genel kurul toplanacağ 1 2012 tarihine kadar üyeliğin uzun süreli askıya alınması kararının "üyelikten çıkarma" niteliğinde olduğuna hükmetmiş ve bu nedenle sendika disiplin kurulunun davacı hakkında verdiği, sendika üyeliğinin ilk genel kurul tarihine kadar askıya alınmasına ilişkin kararının hukuki geçerliliği bulunmadığından yerel mahkeme kararını bozmuştur ${ }^{44}$.

Yargıtay, benzer bir kararda, sendika tüzüğüne göre yöneticilere geçici olarak işten el çektirme cezası verilebileceğini ancak tüzükte belirli bir süre gösterilmemiş olsa dahi "geçici" sözcüğünün anlamına uygun düşecek bir biçimde disiplin kurulu kararında bu sürenin belirtilmiş olması gerektiğini vurgulamıştır. Böyle bir süre gösterilmemişse bu durumda disiplin kurulu

41 Şahlanan, (n 3) 173.

42 Ibid.

43 Erhan Birben, İş Sözleşmesinin İşveren Tarafından Feshinde Ölçülülük İlkesi, (2006) yayınlanmamış doktora tezi, Dokuz Eylül Üniversitesi SBE, 5-6; Michel Fromont, Le principe de proportionnalité, (AJDA 1995) 156 vd.'dan nakleden Deniz Ugan Çatalkaya, (2017) İş Hukukunda Ölçülülük İlkesi (Doktora Tezi). https://tez.yok.gov.tr/UlusalTezMerkezi/ Erişim Tarihi: 20.11.2020

44 Yargitay 9 HD, 30925/34411, 23.11.2010. 
kararının Yasaya ve ana tüzüğe uygun olduğundan söz edilemez ve anılan disiplin kurulu kararının iptaline karar verilmelidir ${ }^{45}$. Yine başka bir karara göre de olağan genel kurul toplantısının uzak bir tarihte olması halinde de olağanüstü genel kurulunun toplantıya çağrılması ve konunun orada görüşülüp bir karara bağlanması gerekir ${ }^{46}$.

Yargıtay 9. HD, 2013 tarihli bir kararında "üyelikten geçici çıkarma cezasinı gerektiren fiillerin kurul üyeleri tarafindan işlenmesi durumunda verilebilen bu cezayl, uzun süreli görevden uzaklaştırma olarak (kurul üyesi) şube genel sekreterine verilmesi üyelikten çıkarma niteliğindedir" şeklinde karar vermiştir. Ancak 2018 tarihli daha yeni bir kararda 22. HD ise; "öncelikle belirtmek gerekir ki, her ne kadar ilk derece mahkemesince, sendika disiplin kurulu tarafindan verilen kararın üyelikten çıkarma niteliğinde olduğu, bu kararın da genel kurul tarafindan verilmesi gerektiği gerekçesiyle dava kabul edilmişse de, sendika tüzügünün 25. maddesinde ayrica düzenlenen görevden uzaklaştırma cezası, üyelikten çıkarma cezasından farklı nitelikte olduğundan, mahkemenin gerekçesi bu yönü itibariyle isabetli değildir" şeklinde karar vermiştir ${ }^{47}$.

Bir kararda Yargıtay, görevden uzaklaştırma cezasını, altı aylık süre ile sınırlandırılmış olduğundan disiplin kurulu kararını Sendika Tüzüğüne dolayisıyla Kanuna uygun bulmuştur. "Dosyadaki bilgi ve belgeler birlikte değerlendirilip disiplin cezasına neden olan olaylart incelendiğinde; davacının şube başkanı olarak görev yaptığ sırada sendika üyesi ve yöneticilerden borç para aldı̆̆g, istenildiğinde ise; davacının borç veren kişilerin yakınlarının işe alındiğı, verilen paraların bunlara sayılması gerektiğini söyleyerek ödemediğini saptanmıştır. Bu durumda davacının kendisine yükletilen disiplin suçunu, şube başkanliğ n nüfuzunu kullanarak işlediği sabit olduğundan genel disiplin kurulunun geçici olarak yöneticilik görevinden ihraç etmesi de ölçülülük ilkesine uygundur. ${ }^{48}$ ",

2.2.2. Disiplin İç Yönetmeliklerinin İptaline İlişskin Karar: Her ne kadar çalışmamız 4688 sayılı Kanunla ilgili olmasa da karardaki incelenen esaslar 6356 sayılı Kanun açısından da aynıdır. Söz konusu uyuşmazlıkta davacılar, sendika yönetim kurulunun, Disiplin Kurulları Yönetmeliğine konulan hükümlerin Anayasanın 51. maddesi hükmüne ve 4688 Sayılı Kamu Görevlileri Sendikaları Kanunu ile ilgili sendikanın tüzüğüne aykırı olduğunu ileri sürerek davalı sendikanın disiplin kurulları yönetmeliğinin ilgili maddelerinin iptaline karar verilmesini talep etmiştir.

\footnotetext{
45 Yargitay $9 \mathrm{HD}, 12865 / 13829,14.12 .1990$

46 Yargitay $9 \mathrm{HD}, 39207 / 32474,20.09 .2011$

47 Yargitay $22 \mathrm{HD}, 14757 / 24473,15.11 .2018$.

48 Yargitay 9 HD, 2700/3801, 06.03.2008.
} 
IIIIIIIIII!

Yerel mahkeme davayı kabul etmiş ve düzenlemenin iptaline karar vermiştir. Karar davalı sendika tarafından istinafa taşınmıştır. Bölge Adliye Mahkemesi, disiplin yönetmeliğinde yapılan değişikliğin, üyelerin sendikal haklarını kullanma imkânını disiplin kurulu kararı ile ortadan kaldıracak nitelikte olduğunu, Anayasa, Uluslararası Çalışma Örgütü normları ve 4688 Sayılı Kamu Görevlileri Sendikaları ve Toplu İş Sözleşmesi Kanunu hükümlerine de aykırı olduğunu belirterek istinaf başvurusunun esastan reddine karar verilmiştir.

İstinaf kararı davalı tarafından temyiz edilmiştir. Yargıtay, sendika tarafından ihdas edilen yönetmelik hükümlerinin iptaline karar verilebileceğini öngören bir hükmün hukukumuzda mevcut olmadığından itibarla, somut uyuşmazlıkta dava konusu düzenlemeler hukuka ve demokratik esaslara aykırı olduğundan, mahkemece geçersizliğinin tespitine karar verilmesi ile yetinilmesi gerektiğine karar vermiş fazlaya dair istemin reddetmiştir ${ }^{49}$. Yargıtay'a göre sendikal özgürlüklerin başında, sendikaların, kurulduktan sonra faaliyetlerinde ve yönetiminde serbest olabilmeleri hususu gelmektedir. Ülkemiz tarafından 1993 yılında onaylanan, Uluslararası Çalışma Örgütü’nün, Sendika Özgürlügüne ve Örgütlenme Hakkının Korunmasına İlişkin 87 Sayılı Sözleşmesi'nin 3'ncü maddesinin ilk fikrasına göre çalışanların ve işverenlerin örgütleri, tüzük ve iç yönetmeliklerini düzenlemek, temsilcilerini serbestçe seçmek, yönetim ve etkinliklerini düzenlemek ve iş programlarını belirlemek hakkına sahiptirler. Bununla birlikte yine Yargıtay, bir özel hukuk tüzel kişisi olan sendika tarafından alınan kararların ve yapılan işlemlerin iptal edilebilmesi için, mevzuatta bu yönde bir düzenlemenin yer alması gerektiğinin altını çizmiştir.

Sendikalarla ilgili birçok husus Kanunda ayrıntılı olarak düzenlenmemiştir. Ancak kanaatimizce Yargıtay'ın kararı da isabetlidir. Sonuçta verilen bu karar zaten bir iptal hükmü gibi sonraki uygulanacak disiplin hükümlerine emsal teşkil edecektir. Burada kamu hukuku anlamında düzenleyici işlem söz konusu değildir. Zaten bu yönde verilecek bir iptal kararı da kuruluşların özerkliği prensibine de aykırı olacaktır ${ }^{50}$.

2.2.3. Üyelikten İhraca İlişkin Disiplin Kurulu Kararına Karşı Dava Açma Süresine İlişkin Karar: Sendika hukukunda disiplin veya diğer kurulların kararlarına (genel kurul seçimleri hariç) karşı açılacak davanın süresine ilişkin bir hüküm yoktur. STISK m.15/2'de, “Bakanlık veya kuruluş ya da şubesinin üye ve delegeleri; kanun ve tüzük hükümlerine aykırı olarak genel kurul ve seçim yapılması veya seçim sonuçlarını etkileyecek ölçüde bir usulsüzlük ya da kanuna aykırı uygulama iddiasıyla, bu işlemlerin veya

49 Yargitay $22 \mathrm{HD}, 6923 / 19042,15.10 .2019$.

50 Bkz. Burak Sabuncu, 'Dernek Organlarının İç İlişkide Birbirlerine Karşı Hukuki Durumları' (2020) S:1, Ankara Barosu Dergisi, 157-190. 
genel kurulun iptali için genel kurul tarihinden itibaren bir ay içerisinde dava açabilir" hükmü yer almaktadır. Ancak bu hüküm, dikkat edilecek olursa sendika seçimlerine yöneliktir.

Konuyla ilgili bir Yargıtay kararına göre ise "Sendika Şube Disiplin Kurulunun geçici uzaklaştırma kararına karşs itiraz merciini sendika tüzüğ̈̈nde belirtmemiş olmasının bu hakkın keyfi kullanılmasına yol açmaması gerekir. Ancak, bu hakkın amacına uygun olarak kullanılıp kullanılmadığını denetlemek sendika tüzü̈̆̈̈nde hüküm olmadı̆̆ından Sendikalar Kanununun 63. maddesi ${ }^{\text {ș }}$ "iş̧̧i ve işveren sendikaları ve konfederasyonları hakkında, bu kanunda hüküm bulunmayan hallerde Medeni Kanun ve Dernekler Kanununun bu kanuna aykırı olmayan hükümleri uygulanır" kuralı uyarınca Medeni Kanunun 68. maddesinde yer alan cemiyet üyelerinin cemiyet organlarının kararlarına karşı kararın öğrenilmesinden başlayarak bir ay içerisinde mahkemeye itiraz edebilmeleri hakkının bulunduğu kabul edilmelidir. ${ }^{52}$ "

Yürürlükteki 4721 sayılı Türk Medeni Kanunu'nun ${ }^{53}$ derneklerle ilgili "kararın iptali” başliklı 83'üncü maddesine göre de "(1) Toplantıda hazır bulunan ve kanuna veya tüzüge aykırı olarak alınan genel kurul kararlarına katılmayan her üye, karar tarihinden başlayarak bir ay içinde; toplantıda hazır bulunmayan her üye kararı ögrenmesinden başlayarak bir ay içinde ve her hâlde karar tarihinden başlayarak üç ay içinde mahkemeye başvurmak suretiyle kararın iptalini isteyebilir". Dolayısıyla burada Yargitay'ın vermiş olduğu karar isabetlidir. Ancak bu hükümden çıkan diğer bir sonuç da, kuruluşun tüzüğünde iç denetim mekanizması düzenlenmişse bu yollara başvurulmuş olma zorunluluğudur. Kanaatimizce, tüzükte bir iç denetim mekanizması varsa buna uyulmalıdır. Tüzükteki itiraz mercilerine başvuru süresi ayrıca belirtilmemişse yine tebliğden itibaren bir ay içinde karara itiraz edilebilir. Örneğin tüzükte şube disiplin kurulunun kararına karşı bir hafta içinde genel disiplin kuruluna başvuru süresi verilmişse, bu süreye uyulmalıdır.

\subsubsection{Hakların Kullanılmasının Disiplin Soruşturmasının Başlamasıyla} Kötü Niyete Dönüşmesine İlişkin Karar: 4721 sayılı Türk Medeni Kanunu'nun 2'nci maddesine göre 'Herkes, haklarını kullanırken ve borçlarını yerine getirirken dürüstlük kurallarına uymak zorundadır (f.1). Bir hakkın açıkça kötüye kullanılmasını hukuk düzeni korumaz (f.2) “. Dürüstlük kuralını, herkesin, haklarını kullanırken ve borçlarını yerine getirirken, ortalama zekâ seviyesine sahip, makul, dürüst ve güvenilir bir kişiden aynı hal ve şartlar

516356 sy Kanundaki karşı1lı̆̆1 80’inci maddedir: “Kuruluşlar hakkında, bu Kanunda hüküm bulunmayan hâllerde 4721 sayıl Kanun ile 4/11/2004 tarihli ve 5253 sayll Dernekler Kanununun bu Kanuna aykırı olmayan hükümleri uygulanır."

52 Yargitay 9 HD, 17143/18948, 13.11.1997.

53 RG, 08.12.2001, 24607. 
IIIIIIIIIII

altında beklenebilecek davranış tarzına uygun şekilde davranma zorunluluğu olarak tanımlanabilir ${ }^{54}$.

Bir uyuşmazlıkta, hakkında disiplin soruşturması açılması kararı verilen sendika yöneticisi, soruşturma açılması kararı verilir verilmez görevinden istifa etmiş ve görevlerinden istifa eden yöneticilere verilen bir ödenekten yararlanmak istemiştir. Yargıtay ise verilen ve genel kurulca onaylanan disiplin kurulu kararını sonuçsuz kılacak şekilde, hizmet ödeneği isteğinin kabulünü hatalı bulmuştur ${ }^{55}$. Karara göre davacının kendi eylemlerinden dolayı sendika yöneticiliği görevinden uzaklaştırılması ve sendika üyeliğinden ihraç edilmesi bir cezalandırma olup sendika yöneticiliği görevinden istifa ederek hukuka aykırı şekilde hizmet ödeneği hakkından yararlanmak istemesi hakkın kötüye kullanılmasını oluşturmaktadır.

Kararda henüz ortada verilmiş bir disiplin kararı yokken gerçekleşen istifa sonucunda, istifaya bağlı olarak ortaya çıkan bir hakkı talep etmenin, bir hakkın talebinin "hakkın kötüye kullanılması olarak değerlendirilmesi" eleştirilebilir. Somut olayda, sendika yöneticisi tedbiren görevden uzaklaştırıldıktan sonra, disiplin kurulunun ihraç kararının hemen öncesinde alması muhtemel bir disiplin cezasının verilecek ödeneğe engel olmasını gözeterek böyle bir müracaat yapmıştırs ${ }^{5}$. Bir hakkın görünen şekliyle kullanılması ile doğru

54 O. Gökhan Antalya ve Murat Topuz, Medeni Hukuk (Giriş - Kavramlar - Başlangıç Hükümleri) (3. Bas1, C.1, Seçkin 2019) 494.

55 Yargitay 9 HD, 1316/6572, 27.03.2008: Dosya içerisinde bulunan bilgi ve belgelerden davacının ... dolayı yürütmekte olduğu sendika yöneticiliği görevlerinden tedbirli olarak el çektirilmesine ve bu görevlerinden sürekli olarak alınmasına ve sendika üyeliğinden kesin ihraç edilmesine karar verildiği ve bu kararın Sendika Merkez Genel Kuruluınun 6-7 Aralık 2002 tarihli toplantısında onaylandığı anlaşılmaktadır.

Sendika Tüzüğ̈̈'nün 53/b maddesinde "Yönetim organlarında ücretli olarak çalışanlardan, seçime girmeme, seçilmeme veya çekilme nedeniyle görevleri sona erenlere Sendikada çalışarak geçen her hizmet yılı için 45 günlük ücret tutarında hizmet ödeneği verilir...." hükmü yer almaktadır. Anılan maddeye göre sendika yöneticiliği görevinden çekilme yani istifa halinde sendika yöneticisine hizmet ödeneği ödenmesi gerekmektedir. Davacı, bu düzenlemeden yararlanmak için hakkında Disiplin Kurulunca soruşturma başlatılır başlatılmaz, hatta tedbirli olarak sendika görevinden el çektirilir çektirilmez, sendika yöneticiliği görevinden istifa etmiş ve hizmet ödeneği isteğinde bulunmuştur. Davacının kendi eylemlerinden dolayı sendika yöneticiliği görevinden uzaklaştırllması ve sendika üyeliğinden ihraç edilmesi bir cezalandırma olup sendika yöneticiliği görevinden istifa ederek hukuka aykırı şekilde hizmet ödeneği hakkından yararlanmak istemesi hakkın kötüye kullanılmasını oluşturur. Hakkın açıkça kötüye kullanılmasını hukuk düzeni korumaz. Bu nedenle mahkemece davacı hakkinda verilen ve genel kurulca onaylanan disiplin kurulu kararını sonuçsuz kılacak şekilde diğer bir deyişle disiplin kurulu kararı iptali niteliğinde olan hizmet ödeneği isteğinin kabulü hatalı olup bozmayı gerektirmiştir.

56 Davalı sendika, şube yöneticisi olarak görev yaptığl sırada şubeye bağlı Teksa işyerinde çalışan üye işçileri sendika üyeliğinden istifa ettirerek başka bir sendikaya üye olmaya zorladığ 1 , şube yönetici ve temsilcilerine hakaret ettiği, bu nedenle Genel Disiplin Kurulu 
şekilde kullanılması ve uygulanması farklı olgulardır ${ }^{57}$. Hakkın kullanılmasıyla bir çelişki ve tutarsızlık ortaya çıkıyorsa, bu durum hakkın kötüye kullanılması yasağ

\subsubsection{Disiplin Kurulunca Verilen Cezanın, Genel Kurulun Gündemine} Alınarak Görüşülmemesine İlişkin Karar: 2821 say1lı Kanun döneminden bir uyuşmazlıkta ${ }^{59}$, üyeye (genel yönetim kurulu genel teşkilatlanma sekreteri) "geçici olarak işten el çektirme" cezası verilmiş daha sonra sendikanın olağan genel kurulu yapılmış, 37 delege davacı hakkındaki genel disiplin kurulu kararının bütün sonuçları ile birlikte ortadan kaldırılmasının görüşülmesini istemişlerdir. $\mathrm{Bu}$ önerge reddedilmiştir. Bunun üzerine üye, dava açarak disiplin kurulunca verilen geçici işten el çektirme cezasının iptalini istemiştir.

Yargıtay, 2821 sayılı Sendikalar Kanunu m.18'e göre üye hakkında disiplin kurulunca üyelikten çıkarma dışında verilen disiplin cezalarının genel kurula bildirilmesi gerektiği, yöneticiler hakkında verilecek disiplin cezalarının genel kurula bildirileceğinin sendika ana tüzügünde de öngörüldüğü, 2908 sayılı Dernekler Kanununa göre toplantıda hazır bulunan üyelerin en az onda biri tarafından görüşülmesi istenen konuların gündeme alınmasının zorunlu olduğu ve bu durum karşısında isteğin gündeme alınmasının gerektiği gerekçesiyle, konunun olağan genel kurulunda gündeme alınıp görüşülmemiş olmasının davacı aleyhine hukuki sonuç doğurmaması gerektiğine karar vermiştir.

2821 sayıl Kanundaki "Disiplin kurulu, sendika veya konfederasyonun tüzüğ̈̈ne, amaç ve ilkelerine aykırı hareket ettiği ileri sürülen üyeleri hakkında soruşturma yapar, üyelikten çıkarma dışındaki tüzügünde gösterilen disiplin cezalarını verir ve sonucunu genel kurula ve diğer ilgililere bildirir" hükmü 6356 sayılı Kanunda muhafaza edilmemiştir. Ancak yürürlükten kalkan 2908 say1lı Dernekler Kanunu 25'inci maddesindeki hüküm, yürürlükteki 4721 say1lı Türk Medeni Kanununun 79/2'nci maddesinde tekrarlanmıştır: “Genel kurul toplantısında yalnız gündemde yer alan maddeler görüşülür. Ancak, toplantıda hazır bulunan üyelerin en az onda biri tarafindan görüşülmesi yazılı olarak istenen konuların gündeme alınması zorunludur. ” Burada şu soru akla gelebilir. Üyelikten çıkarma dışındaki bir karar, genel kurulda gündeme

tarafindan tedbiren yürütmekte olduğu görevlerden 9.6.2001 tarihinde uzaklaştırıldığı, 24.6.2001 tarihinde de Tüzüğün 25/1 maddesi gereğince sürekli olarak yöneticilik görevinden uzaklaştırılmasına ve üyelikten ihracına karar verildiği, kararın 6-7.12.2003 tarihlerinde yapılan Sendika Genel Kurulunda onaylandığı, davalı sırf hizmet ödeneği almak için geçici uzaklaştırma kararından sonra 11.6. 2001 tarihinden sendika yöneticiliği görevinden istifa ettiğini, oysa Sendika Tüzüğünün 53. maddesinde görevden uzaklaştırma halinde hizmet ödeneğinin ödeneceğine ilişkin bir düzenlemenin bulunmadığını savunarak davanın reddini istemiştir.

57 Antalya ve Topuz (n 55) 494.

58 Ibid.

59 Yargitay 9 HD, 7799/9941, 8.10.1990. 
IIIIIIIIII!

alınırsa, bu durumda genel kurul bu konuda karar verebilir mi? Bu halde öncelikle tüzüğe bakmak gerekir. Tüzükte bu konuda hüküm varsa ona göre hareket edilmelidir. Tüzükte bu konuya dair bir hüküm yoksa kanaatimizce, üyelikten çıkarma dışındaki disiplin kurulu kararlarının genel kurulda tartış1lması sonucu değiştirmemelidir.

\section{SONUÇ}

Çalışmamızda sendikalarda zorunlu organlar arasında olan disiplin kurulları, mevzuat ve yargı kararlarıyla değerlendirilmiştir. Disiplin kurulunun görev ve yetkilerinin daha ziyade uygulama ve içtihatlarla geliştiği söylenebilir. Çalışmamızda özetle şu kanaatlere varılmıştır:

Bizzat disiplin kurulu tarafından, kendi üyeleri arasından veya dışından bir ön soruşturmacı ya da rapor yazıcı görevlendirilmesi, genel kurul ile yönetim, denetim ve disiplin kurullarının görev ve yetkilerinin ihtiyari organlara devredilemeyeceği ilkeyle çelişmez.

Kuruluşların tüzüklerinde disiplin kurullarının resen soruşturmaya başlayabileceğine yönelik hüküm varsa kurul resen de soruşturma yapabilecektir.

Kuruluş ve şube yönetim, denetleme ve disiplin kurulu üyelerinin görevleri, milletvekili veya belediye başkanı seçilmeleri hâlinde kendiliğinden son bulur. Sendikalar kamu tüzel kişisi olmadığı gibi, organlarda görev alan kişiler de kamu görevlisi değildirler. Ancak yine de genel kurulda kamu görevi statüsünden kaynaklanan idari gücün oy temini için siyasi bir güç olarak kullanılması söz konusu olabilir.

Tüzükte disiplin kurulunun çıkarma cezası dışında vereceği kararlara karşı bir itiraz mekanizması göstertilmişse (mesela yönetim kuruluna itiraz) evvela bu yollar tüketilmelidir. Ondan sonra mahkemeye başvurulabilir. Kuruluş tüzüğünde herhangi bir hüküm yoksa kesin nitelikteki bu karara karşı iptal davası açılması mümkündür.

Yönetim kurulunun disiplin kuruluna sevk kararının iptali mümkün değildir. Ancak yönetim kurulu, disiplin kurulunun ceza verilmesine yer olmadığına dair kararına karşı yargı yoluna başvurabilir.

Yönetim kurulu, disiplin kurulunun ceza verilmesine yer olmadığına dair kararına karşı şayet disiplin kurulu üyeyi çıkarma sevkiyle yargılamışsa ve yaptırım uygulamamaya karar vermişse, yönetim kurulu konunun görüşüleceği genel kurulda itirazlarını yapabilir ve genel kurul kararını yargıya taşıyabilir. Üyelikten çıkarma dışındaki sevklerle ilgili, yargılama yapılmış ve disiplin kurulu herhangi bir yaptırım uygulanmaması yönünde karar vermişse bu defa yönetim kurulu, genel kurulun toplanmasını beklemeden karara karşı mahkemeye başvurabilir. 
Disiplin iç yönetmeliğine konulan hükümlerin Anayasaya Kanuna ve ilgili sendikanın tüzüğüne aykırı olduğunu ileri sürerek ilgili maddelerinin iptaline karar verilmesinin mahkemeden talep edilmesi durumunda, , yönetmelik hükümlerinin iptaline karar verilebileceğini öngören bir hüküm mevzuatımızda yer almadığında, mahkeme tarafından ilgili maddenin iptaline karar verilemeyecek, yalnızca söz konusu maddenin geçersizliğinin tespitine karar verilmekle yetinilecektir.

Sendika hukukunda disiplin veya diğer kurulların kararlarına (genel kurul seçimleri hariç) karşı açılacak davanın süresine ilişkin bir hüküm yoktur. Disiplin kurulu kararlarına itirazda süreyle ilgili olarak, tüzükte bir iç denetim mekanizması varsa buna uyulmalıdır. Tüzükteki itiraz mercilerine başvuru süresi ayrıca belirtilmemişse yine tebliğden itibaren bir ay içinde karara itiraz edilebilecektir.

Üyelikten çıkarma konusunda son kararı genel kurul verir. Üyelikten çıkarma dışındaki bir karar, genel kurulda gündeme alınırsa, bu halde öncelikle tüzüğe bakmak gerekir. Tüzükte böyle bir ihtimal hakkında hüküm varsa ona göre hareket edilmelidir. Tüzükte bu konuya dair bir hüküm yoksa üyelikten çıkarma dışındaki disiplin kurulu kararlarının genel kurulda tartışılması sonucu değiştirmemelidir.

\section{KAYNAKLAR}

Abdulhakimoğulları E ve Erdinç B, 'Kamu Görevlilerinin Milletvekilliği Seçimlerine Katılmak Üzere Görevden Çekilmeleri ve Göreve Dönmeleri' (2015) C. XIX, Sa. 4, Gazi Üniversitesi Hukuk Fakültesi Dergisi 227-258.

Akyiğit E, Toplu Iş̧ Hukuku (2.Bası, Seçkin 2020) 246.

Antalya OG ve Topuz M, Medeni Hukuk (Giriş - Kavramlar - Başlangıç Hükümleri) (3. Bas1, C.1, Seçkin 2019) 494.

Aydın M, 'Sendika İçi Demokrasinin Sağlanmasında 6356 Sayılı Sendikalar ve Toplu İş Sözleşmesi Kanununun Yeri’ (2016), 4. Sayı, İş ve Hayat Dergisi, 9-58.

Aydın U ve Keskin Ö, '2821 Sayılı Kanundan 6356 Sayılı Kanuna: Türkiye’de Sendikalar Hukukunun Dönüşümü’ (2015) C.1, S.2, Anadolu Üniversitesi Hukuk Fakültesi Dergisi, 1-41.

Çatalkaya DU, (2017) İş Hukukunda Ölçülülük İlkesi (Doktora Tezi). https:// tez.yok.gov.tr/UlusalTezMerkezi/ Erişim Tarihi: 20.11.2020

Çelik N, Caniklioğlu N ve Canbolat T, İş Hukuku Dersleri (31.Bası, Beta 2018) 830 .

Ekmekçi Ö, Toplu Işs Hukuku Dersleri (2.Bası, On İki Levha 2019) 102. 
IIIIIIIIII!

Engin Bİ, 'Dernek Disiplin Kurulu Tarafından Verilen Geçici İhraç Kararına

Karşı İptal Davası Açılamayacağına Dair Yargıtay Hukuk Genel Kurulu Kararının Düşündürdükleri' (2003) C. LXI, S. 1-2, IÜHHFM, 277-312.

Esener T ve Bozkurt Gümrükçüoğlu Y, Sendika Hukuku (2. Bas1, Vedat Kitapç1lık 2017) 199.

Kaya C, 'Milletvekili ve Mahalli İdare Seçimlerine Katılan Kamu Görevlilerinin Görevden Çekilmesi ve Göreve Dönmesi' (2004) C. 13 (Sa. 1) Çağdaş Yerel Yönetimler Dergisi, https://dergipark.org.tr/tr/download/article-file/789851 Erişim Tarihi 10.03.2021;

Lordoğlu K ve Demirdizen D, 'Türkiye'de Sendika İçi Demokrasi ya da Bir İmkânsızın Arayışı mı?' (2013) V. Sosyal Haklar Uluslararası Sempozyumu, İstanbul, Petrol İş Yayını, 223-241.

Özer HD, ‘İşçi Sendikalarında Delegelik’ (2020) Temmuz, C:11, S:2, Çalışma İlişkileri Dergisi, 22-58.

Sabuncu B, 'Dernek Organlarının İç İlişkide Birbirlerine Karşı Hukuki Durumları' (2020) S:1, Ankara Barosu Dergisi, 157-190.

Sur M, İş Hukuku Toplu İlişkiler (6.Bası, Turhan 2017) 145.

Sümer HH, İş Hukuku Uygulamaları (7. Bası, Seçkin 2019) 503.

Şahlanan F, Toplu İş Hukuku (1.Bası, On İki Levha 2020) 191.

Şahlanan F, '6356 Sayılı Sendikalar ve Toplu İş Sözleşmesi Kanunun Sendikalara İlişkin Hükümlerin Değerlendirilmesi' (2013) Çalışma ve Toplum, (39), 110-142.

Tuncay AC ve Savaş Kutsal FB, Toplu Işs Hukuku (5. Bası, Beta 2016) 100.

Uçkan B, “Türkiye'de Kamu Görevliliği Sendikacılığı” (1.Bası, Legal 2013) 56. 